\title{
Capital Markets \& Economic Growth: A Tale of BRICS Countries
}

\author{
Sunita Mall \\ MICA-The School of Ideas \\ Tushar R. Panigrahi \\ ITM Business School
}

The GDP growth of any economy acts as a proxy of the overall growth of that economy. This paper attempts to investigate the significance of economic growth based on economic factors. Several factors contribute to the economic growth. Moreover, foreign direct investment (FDI) bridges the gap of saving and investment in the capital formation and thus supports for economic growth. In this paper, we examine the significant effect of the economic indicators on the GDP growth and the extent of influence. The focus of this paper is also to check if the significant economic indicators of GDP growth is consistent across the economies. We consider the data of fifteen economic indicators for BRICS countries over a period of 1990 to 2018. For this purpose, we employ Karl Pearson's correlation and regression model. The result reveals that final consumption expenditure, gross capital formation, general government final consumption expenditure affect the GDP growth of Brazil, gross capital formation, general government final consumption expenditure affect the GDP growth of Russia whereas the foreign direct investment, gross capital formation (annual \% growth), gross savings (\% of GDP) affect the GDP growth of China. The household final consumption expenditure per capita growth and gross capital formation affect significantly the GDP growth of India. Final consumption expenditure, household final consumption expenditure, gross savings (\% of GDP), affects South Africa's GDP growth. The result of this paper has important implications for the policy makers.

Keywords: Foreign Direct Investment, Economic Growth, Capital Formation, BRICS Countries, Gross Saving

\section{INTRODUCTION}

The size of any economy is measured from its GDP. The GDP growth rate also indicates the speed of the growth of any economy. Thus, we consider GDP and its growth as the proxy of overall growth of any economy. The economic growth of a country depends on several factors like social, political, economic and cultural parameters. Capital formation, saving-investment ratio, literacy level \& education, private consumption expenditure, government expenditure, etc are the basic socio-economic factors that broadly affect the economic growth. The developing economies face capital deficiency as their investment needs are always higher than the domestic savings and thus they need the external support, which may come in 
the form of foreign direct investment (FDI). According to world investment report of World Bank (2018), some of the developing economies are growing at a higher rate than that of the developed economies. These economies belong to the category of emerging economies. Some emerging economies like Brazil, Russia, India, China and South-Africa (BRICS) have a growth even during the global recession of 2007 2012. In 2016, the BRICS economic group contributed 20\% of the World GDP whereas the group accounted for only $11 \%$ of FDI inflow. International Monetary Fund (IMF) also estimates that the emerging market and developing economies contributes 60\% to the world GDP.

China's GDP is the highest amongst the BRICS nations \& in Asian economies too. It has the second position in the GDP in the world ranking after the United States. India has the seventh position in nominal GDP whereas Brazil, Russia and South Africa stand at $8^{\text {th }}, 11^{\text {th }}$ and $33^{\text {rd }}$ position in the world respectively. Thus, they have a separate identity altogether from their continuous growth point of view. For some of the countries the growth triggers are similar whereas for some others it is different.

Moreover, the ranking of these countries are different with respect to their respective FDI inflow. Brazil, Russia, India, China and South Africa hold $7^{\text {th }}, 25^{\text {th }}, 12^{\text {th }}, 4^{\text {th }}$ and $68^{\text {th }}$ positions respectively for the year 2015(UNCTAD report 2016 \& World Bank Report 2016). Both UNCTAD Report and World Bank report of 2017 reveal that Brazil, Russia, India, China and South Africa hold 7th, 15th, 11th, 3rd, and 68th positions respectively for the year 2016 for 2017 it is $4^{\text {th }}, 16^{\text {th }}, 10^{\text {th }}, 2^{\text {nd }}$, and $81^{\text {st }}$ positions respectively (UNCTAD report 2016) and India's position in FDI inflow in the world ranking was $10^{\text {th }}$ in the year 2017-18.

The BRICS countries together make up over 40 percent of world's population. Russia and Brazil, which currently reach the highest GDP per capita values of all BRICS countries, only reach one sixth of the corresponding value of USA. The existing reports shows that the global FDI ranking of these five countries have been improving consistently. This study attempts to find the significant indicator of FDI inflow for the BRICS countries and checks whether FDI inflow is a significant indicator of the economic growth for the BRICS countries.

Some of the existing studies have been attempted to examine the effect of FDI inflow on economic growth in different context. One of the earlier studies by Feenstra and Markusen ${ }^{5}$ (1994) examined the importance of FDI in transferring and improving the technical knowledge and the skills of the host country's factors of production in long run. Thus, FDI has a spillover effect on the production and the factors of production through positive externalities, which leads to higher growth. However, Hanson (2001) has argued that FDI has a weak positive spillover effect on the host countries. Alam (2000) has opined that FDI has a growth impact both in the economies of India and Bangladesh. Kumar and Pardhan (2001) have remarked that in the developing economies FDI is a solution to the capital deficiency from the external financial resources, which leads to economic development. Kwang \& Singh (1996) using correlation and regression remarked that favorable conditions of running the business of the host country attracts more FDI. The study also highlighted that socio-political instability though difficult to measure as a qualitative variable has a negative impact on FDI. GDP growth rate and FDI inflow are directly related though not proportionate (Billingto,1999, Kravis and Lipsey'1982, Wheeler and Mody' 1992). Studies by Davis and Weinstein, (1999 and 2003) revealed that the ease of access and the local market size of neighboring countries and their markets have a strong influence on the FDI. If the local market size is big and they are liberal to encourage globalization, then attracting more FDI is easy for them.

Yakhou \& Dorweiler, (2006) documented that FDI attractiveness is significantly higher in the developing countries amongst the developed, developing and controlled economies. They supported the results of Head \& Sorensen (2005), that the "developing" economies do understand the foreign investors need to gain economic growth and thus they are taking most active and prompt steps for attracting the FDI in comparison to the rest of the economies in general.

It is very essential for the investors and policy makers to understand the determinants of economic growth for the BRICS countries. In this study, we consider twenty economic indicators for the BRICS nations over a period from 1990 to 2018. Multiple regression model is built for each of the BRICS countries to identify the significant determinants of economic growth. The relevance of considering this period is that in 1991, we got liberalization, privatization and globalization in our economic reform. The 
purpose of choosing BRICS countries is that these are the most developed economies and they have adopted the economic strategies for accelerating economic growth. Using the statistical and empirical analysis, this study tries to draw the insights on the following objective:

a. Identifying significant determinants of economic growth in the BRICS nation

b. Examining whether foreign direct investment is a significant governing factor of the economic growth of all the BRICS countries.

The rest of the study is organized in the following fashion: section 2 deals with literature review, in section 3 research strategy is discussed, and section 4 covers statistical analysis with interpretation and section 5 includes conclusion and implication of the study.

\section{EXTANT LITERATURE}

The financial market transactions and its process has changed largely due to globalization and availability of advanced information technology. Thus the financial markets of countries across the globe are inter connected and inter -related. This is possible due to the involvement and participation of the local markets and huge spread of financial intermediaries. (Schmukler, 2004). Easy and quick transformation of high capital movement liberalization and free flow capital across markets is possible due to advanced information technology. (Gallo, G.M, Otranto, E., 2007). A group of studies stated that a financial system with effective financial functions would contribute to the economic growth in the long term. Few noteworthy among existing studies are King and Levine,1993; Arestis \& Demetriades, 1997; Thiel,2001; Levine,2004; Lawrence, 2006; Shan \& Jianhong,2006.

The role of stock market development on economic growth in Nigeria is studied by Achugbu (2012) and the result revealed that market capitalization and value traded ratio has a strong positive correlation with economic growth. Some other research has a contradictory result. Harris (1997) documented that stock market very weakly associated with the economic development.

\section{Capital Market and Foreign Direct Investment on Economic Growth}

Extensive literature is available on examining the impact of capital market and FDI on economic growth of a country(s).

FDI has a spillover effect on the production and the factors of production through positive externalities, which leads to higher growth. FDI transforms and improves the technical knowledge as well as the skill of the host country's factors of production for a longer period (Feenstra and Markusen, 1994). Some other studies have examined the determinants of FDI to developing countries. Time series analysis is employed for single country analysis whereas for multiple countries panel data analysis is used. (Biswas, 2002; Jadhav, 2012; Rogmans \& Ebbers, 2013). Using panel data over a period of ten years Jadhav (2012) examined the role of economic, institutional and political factors in attracting FDI to BRICS countries and documented that FDI to BRICS is largely market oriented. The findings reveal that market size, openness to trade and rule of law plays significant role in attracting FDI to BRICS. Asiedu (2002) studied the determinants of FDI to developing countries in specific to Africa. He documented that low infrastructure development, return on capital and unfavorable geographic location of many subSaharan Africa countries are responsible for the low FDI inflow. A study by Rogmans \&Ebbers (2013) focused on the determinants of FDI to the Middle East and North Africa region. He used panel data from 1987 to 2008 and the result revealed that natural resources endowment contributes negatively to FDI flows whereas trade openness has a positive effect.

Kamath (2009) studied the FDI data along with the economic growth indicators such as GDP, exchange rate, interest rate, human capital, technological factor and openness of the economy for Asian countries over a period from 1985 to 2005 by taking world investment data from world investment report 2006. He used regression analysis to find out the relevance of the studied indicators to decide the FDI inflow to India. He remarked that the model lacks relevance in the Indian context as the study period has both the pre-liberalization and post-liberalization period and thus the post liberalization information on 
the economic indicators are not sufficient to measure the impact on the FDI inflow. The result reveals that the human capital influences the FDI inflow to India.

Cheng and Kwan (2000) documented that FDI inflow is positively affected by infrastructure, policy designations (i.e. SEZs) and regional income where as it is negatively affected by the wage cost in China. They have considered labour wage, per capita income, education level and policy designs along with the above-mentioned variables to examine their impacts on FDI inflow in China.

Singh and Paul (2013) compared the developing economies with the developed ones with respect to FDI inflow and documented that developing nations like India, China, Brazil, etc. attract higher quantity of inward FDI than that of the developed ones. Panigrahi \& Mall (2017) used Polynomial method of second-degree quadratic equation on the time-series data to predict the ranks of different economies of Asia based on the FDI inflow to Asia. They found China, Hong Kong and Singapore are continuing at first, second and third position respectively and India has the fourth rank in achieving the inward FDI.

Studies by Ahluwalia ${ }^{1}$ (2001) and Panigrahi, T.R. (2015) examined the association between the strength of investment climate in the Indian states and the foreign investors choice of location for bringing FDI. The states, weak in terms of investment climate, could not attract the FDI as expected whereas the states with strong investment climate attracted a significant share of FDI in India.

Several studies also went on examining the impact of capital markets and FDI on economic growth. Khetsi, Q.S, Mongale, I.P. (2015) investigated the impact of capital markets on economic growth in South Africa over a period of 1971-2013. The result reveals that there is a positive relationship between economic growth and capital markets in South Africa. Using capital market activity variables over a period of 2000-2012, Leene, T.L., Oki, J.(2017) investigated whether capital market development and directly translated to economic growth of MINT, They documented that the number of listed securities is the most impacting capital market development measure on economic growth of the MINT as a group. This indicator was seen to be negative and significantly related to GDP.

Another strand of researchers have studied the determinants, trends and patterns of FDI flows to BRICS economies. Examining the trends and patterns of FDI flows in BRICS economies during the period from 1990 to 2015, Bose, S. \& Kohli, B. (2018) has documented that developed markets are still considered to be drawing the lion's share of FDI, claiming the top slots in global FDI inflows. They also documented that if the high-performing emerging markets have investor's preferred market characteristics, they can continue to attract FDI inflows. The study by Asongu, S.A., Akpan, U.S., Isihak, S.R(2018) examined the determinants of foreign direct investment to BRICS and MINT using the data over a period of 2001 to 2011. They employed pooled time-series cross-sectional analysis to estimate the model on determinants of FDI on BRICS, MINT and BRICS \&MINT combined and documented that market size, infrastructure availability and trade openness are the main factors that attract FDI to BRICS and MINT. Using the panel data analysis over a period from 1989 to 2010 a study by Mercan, M., Gocer, I. (2013) examined the effect of financial development on economic growth for BRIC-T countries. The effect of FDI and trade openness on economic growth was also studied. The result shows that the effectof financial development on economic growth was positive. Employing the framework of VAR model and considering the proxy indicators of both stock market development and economic growth, Ali, A.S. (2015) examined the linkages between stock market development and economic growth. They documented that stock market development positively and significantly affects the economic growth of Russia, India and China. Granger causality model revealed the influence of stock market development of economic growth of BRICS. A study by Osaseri, G., Osamwongi, I.O. (2019) examined the impact of stock market development on economic growth of BRICS. He used panel least square based on the fixed effect estimation on the quarterly time series data over a period of 1994 to 2015 . The findings revealed that stock market development shows significant impact on the economic growth and shares a positive association with the economic growth of BRICS countries.

Our study is about identifying the determinants of economic growth for the BRICS countries and to examine whether FDI is a significant and common factor of economic growth to all BRICS countries. 


\section{RESEARCH METHODOLOGY}

The empirical analysis of this study includes the secondary data collected from the investment report 2018 and the World development indicators 2018 of World Bank publications for BRICS countries. In this study, we consider twenty economic indicators such as GDP growth, fixed capital formation (\% of GDP), Stocks traded, total value (\% of GDP), adjusted savings: consumption of fixed capital (\% of GNI), gross capital formation ( $\%$ of GDP), domestic credit to private sector by banks ( $\%$ of GDP), gross capital formation (annual \% growth), final consumption expenditure (annual \% growth), domestic credit to private sector by banks ( $\%$ of GDP), general government final consumption expenditure (annual \% growth), household final consumption expenditure (annual $\%$ growth), foreign direct investment, net inflows ( $\%$ of GDP), gross savings ( $\%$ of GDP), gross domestic savings ( $\%$ of GDP). This study aims to identify the determinants of Economic growth and to examine whether FDI is a significant fact of the economic growth for all the BRICS countries.

We employed correlation analysis to check the association between the economic indicators. We used multiple regression model to investigate the significant effect of the economic indicators on the economic growth of the BRICS countries. We performed descriptive statistics to understand the basic characteristics of the economic indicators.

\section{Stepwise Regression Model}

Stepwise regression model is one of the widely used regression model. Performing a series of t-test and F-test, this regression technique builds a model by adding and removing the predictor variables. The decision of adding and removing variables are decided based on the test statistic of the coefficients estimated. In stepwise regression model, we get the standardized regression coefficient as:

$$
\mathrm{B}_{\mathrm{std}}=\mathrm{b}\left(\frac{S x}{S y}\right)
$$

where, Sx, Sy are the standard deviations for the dependent and independent variable respectively. The percentage change in the square root of mean square error due to addition or deletion of specified variables is called root mean square error. The percent change in root mean square error is calculated as below:

$$
\text { Percent change }=\left[\frac{\text { RMSE previous }- \text { RMSE current }}{R M S E \text { current }}\right] 100
$$

Stepwise regression performs multiple regression a number of times, each time removing the weakest correlated variables and finally sharing most significant variables.

\section{EMPIRICAL ANALYSIS}

The objective of this study is examined using empirical and statistical analysis. The result of this study is discussed in this section.

\section{Analysis of Economic Indicators: Case of BRAZIL}

The result of descriptive analysis Table-1 (Appendix-1) reveals that there is no discrepancy in the characteristics of the variables, as far as the statistical properties are concerned. This table shows that the variables like BZA Final consumption expenditure, etc. (annual \% growth), BZA General Government final consumption expenditure (annual \% growth) have a higher co-efficient of variation than that of the rest of the variables.

We employed correlation analysis, to investigate the association between the economic indicators. The result shows that, Brazil's GDP has strong positive association with its gross capital formation, final consumption expenditure and household final consumption expenditure (with a coefficient of 0.865 , 
0.876 and 0.72 respectively). On the other hand, it has moderate association with its gross capital formation, general government final consumption expenditure and BZA gross domestic savings. (With a coefficient of $0.453,0.541$ and 0.428 respectively). This association is statistically significant at $5 \%$ level of significance. To find the significant economic indicator, we used stepwise regression and result is as follows:

TABLE 3

MODEL SUMMARY

\begin{tabular}{|c|c|c|c|c|c|c|c|c|c|}
\hline \multirow[b]{2}{*}{ Model } & \multirow[b]{2}{*}{$\mathrm{R}$} & \multirow[b]{2}{*}{$\begin{array}{l}\mathrm{R} \\
\text { Square }\end{array}$} & \multirow[b]{2}{*}{$\begin{array}{l}\text { Adjusted } \\
\text { R Square }\end{array}$} & \multirow[b]{2}{*}{$\begin{array}{l}\text { Std. Error of } \\
\text { the Estimate }\end{array}$} & \multicolumn{5}{|c|}{ Change Statistics } \\
\hline & & & & & $\begin{array}{l}\text { R Square } \\
\text { Change }\end{array}$ & $\begin{array}{l}\text { F } \\
\text { Change }\end{array}$ & df1 & $\mathrm{df} 2$ & $\begin{array}{l}\text { Sig. F } \\
\text { Change }\end{array}$ \\
\hline 1 & $.876^{\mathrm{a}}$ & .767 & .758 & 1.43275 & .767 & 82.278 & 1 & 25 & .000 \\
\hline 2 & $.959^{\mathrm{b}}$ & .919 & .913 & .86074 & .152 & 45.268 & 1 & 24 & .000 \\
\hline 3 & $.975^{\mathrm{c}}$ & .950 & .943 & .69242 & .031 & 14.087 & 1 & 23 & .001 \\
\hline \multicolumn{10}{|c|}{ a. Predictors: (Constant), BZA Final consumption expenditure, etc. (annual \% growth) } \\
\hline \multicolumn{10}{|c|}{$\begin{array}{l}\text { b. Predictors: (Constant), BZA Final consumption expenditure, etc. (annual \% growth), BZA Gross } \\
\text { capital formation (annual \% growth) }\end{array}$} \\
\hline \multicolumn{10}{|c|}{$\begin{array}{l}\text { c. Predictors: (Constant), BZA Final consumption expenditure, etc. (annual \% growth), BZA Gross } \\
\text { capital formation (annual \% growth), BZA General government final consumption expenditure (annual } \\
\% \text { growth) }\end{array}$} \\
\hline
\end{tabular}

Table-3 displayed below shows that, final consumption expenditure; gross capital formation and general government final consumption expenditure contributed $94.3 \%$ of variability in explaining the GDP growth of Brazil. The $\beta$ coefficients are in the table below and has several explanatory power. 
TABLE 4

COEFFICIENTS

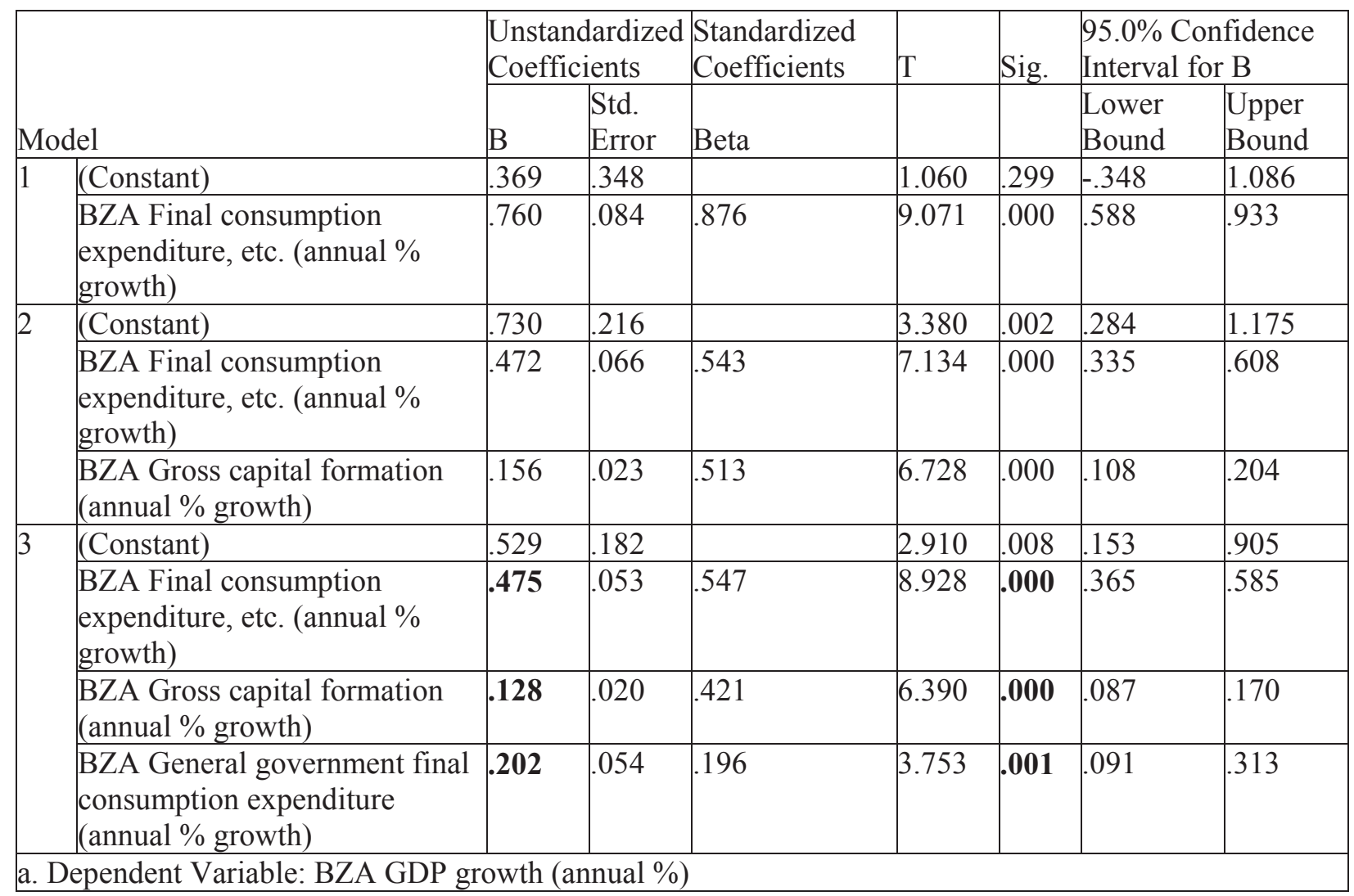

It is evident from Table-4 that Brazil's GDP growth is explained by its final consumption expenditure, gross capital formation and the general government final consumption expenditure, which are statistically significant as their P-values are $0.000,0.000$, and 0.001 . The result also reveal that the $\beta$ coefficients for these three variables are $0.475,0.128$ and 0.202 respectively. This has high explanatory power. It signifies that for one unit change in final consumption expenditure, gross capital formation and general government final consumption expenditure, there would be an increment of $47 \%, 12 \%$ and $20 \%$ respectively in the GDP growth of Brazil.

\section{Analysis of Economic Indicators: Case of RUSSIA}

We performed the correlation analysis to examine the association between the economic indicators. The result of correlation analysis given in table-3 (Appendix). The result shows that Russia's GDP has significant strong positive association with its gross capital formation and final consumption expenditure with a coefficient of 0.827 and 0.725 respectively. Gross fixed capital formation and gross capital formation and consumption of fixed capital have a negative association with the GDP growth of Russia. This association is statistically significant at $5 \%$ level of significance. We performed stepwise regression to find the significant economic indicators. The result is as follows: 
TABLE 5

MODEL SUMMARY

\begin{tabular}{|c|c|c|c|c|c|c|c|c|c|}
\hline \multirow[b]{2}{*}{ Model } & \multirow[b]{2}{*}{$\mathrm{R}$} & \multirow[b]{2}{*}{$\begin{array}{l}\mathrm{R} \\
\text { Square }\end{array}$} & \multirow[b]{2}{*}{$\begin{array}{l}\text { Adjusted } \\
\text { R Square }\end{array}$} & \multirow{2}{*}{$\begin{array}{l}\text { Std. Error } \\
\text { of the } \\
\text { Estimate }\end{array}$} & \multicolumn{5}{|c|}{ Change Statistics } \\
\hline & & & & & $\begin{array}{l}\text { R Square } \\
\text { Change }\end{array}$ & F Change & df1 & $\mathrm{df} 2$ & $\begin{array}{l}\text { Sig. F } \\
\text { Change }\end{array}$ \\
\hline 1 & $.827^{\mathrm{a}}$ & .684 & .671 & 3.83359 & .684 & 54.082 & 1 & 26 & .000 \\
\hline 2 & $.906^{b}$ & .821 & .806 & 2.94627 & .137 & 18.326 & 1 & 25 & .000 \\
\hline
\end{tabular}

It is clear from Table-5, gross capital formation, general government final consumption expenditure together is contributing $80 \%$ of the variation in the GDP growth of Russia. The $\beta$ coefficients signifies the following interpretations:

TABLE 6

COEFFICIENTS

\begin{tabular}{|c|c|c|c|c|c|c|c|c|}
\hline \multirow{2}{*}{\multicolumn{2}{|c|}{ Model }} & \multicolumn{2}{|c|}{$\begin{array}{l}\text { Unstandardized } \\
\text { Coefficients }\end{array}$} & \multirow{2}{*}{$\begin{array}{l}\text { Standardized } \\
\text { Coefficients } \\
\text { Beta }\end{array}$} & \multirow[t]{2}{*}{$\mathbf{T}$} & \multirow[t]{2}{*}{ Sig. } & \multicolumn{2}{|c|}{$\begin{array}{l}95 \% \text { Confidence } \\
\text { Interval for B }\end{array}$} \\
\hline & & B & Std. Error & & & & $\begin{array}{l}\text { Lower } \\
\text { Bound }\end{array}$ & $\begin{array}{l}\text { Upper } \\
\text { Bound }\end{array}$ \\
\hline \multirow{2}{*}{1} & (Constant) & .931 & .738 & & 1.261 & .219 & -.590 & 2.452 \\
\hline & $\begin{array}{l}\text { RA Gross capital } \\
\text { formation (annual \% } \\
\text { growth) }\end{array}$ & .216 & .029 & .827 & 7.354 & .000 & .156 & .277 \\
\hline \multirow{3}{*}{2} & (Constant) & 1.496 & .583 & & 2.568 & .017 & .294 & 2.699 \\
\hline & $\begin{array}{l}\text { RA Gross capital } \\
\text { formation (annual \% } \\
\text { growth) }\end{array}$ & .173 & .025 & .662 & 6.995 & .000 & .122 & .224 \\
\hline & $\begin{array}{l}\text { RA General government } \\
\text { final consumption } \\
\text { expenditure (annual \% } \\
\text { growth) }\end{array}$ & .624 & .146 & .405 & 4.281 & .000 & .323 & .925 \\
\hline
\end{tabular}

Table-6 highlights that gross capital formation, general government final consumption expenditure explains Russia's GDP growth. The $\beta$ coefficients of these two variables are 0.173 and 0.624 respectively, which signifies that for 1 unit increase in these two variables, the GDP growth of Russia would increase by $17 \%$ and $62 \%$ respectively.

\section{Analysis of Economic Indicators: Case of INDIA}

The result of correlation analysis confirms that, India's GDP has significant moderate positive relation with its gross capital formation, gross fixed capital formation, private sector, gross capital formation, household final consumption expenditure per capita growth, gross savings and gross domestic savings with a coefficient of $0.602,0.515,0.632,0.728,0.648$ and 0.669 respectively. Stepwise regression output explains the significant economic indicators. The result is as follows: 
TABLE 7

MODEL SUMMARY

\begin{tabular}{|c|c|c|c|c|c|c|c|c|c|}
\hline \multirow[b]{2}{*}{ Model } & \multirow[b]{2}{*}{$\mathrm{R}$} & \multirow[b]{2}{*}{ R Square } & \multirow[b]{2}{*}{$\begin{array}{l}\text { Adjusted } \\
\text { R Square }\end{array}$} & \multirow[b]{2}{*}{$\begin{array}{l}\text { Std. Error of } \\
\text { the Estimate }\end{array}$} & \multicolumn{5}{|c|}{ Change Statistics } \\
\hline & & & & & $\begin{array}{l}\text { R Square } \\
\text { Change }\end{array}$ & F Change & df1 & $\mathrm{df} 2$ & $\begin{array}{l}\text { Sig. F } \\
\text { Change }\end{array}$ \\
\hline 1 & $.728^{\mathrm{a}}$ & .530 & .511 & 1.53459 & .530 & 28.194 & 1 & 26 & .000 \\
\hline 2 & $.912^{b}$ & .831 & .817 & .93840 & .301 & 42.857 & 1 & 25 & .000 \\
\hline \multicolumn{10}{|c|}{ a. Predictors: (Constant), IND Household final consumption expenditure per capita growth (annual \%) } \\
\hline \multicolumn{10}{|c|}{$\begin{array}{l}\text { b. Predictors: (Constant), IND Household final consumption expenditure per capita growth (annual \%) } \\
\text { IND Gross capital formation (annual \% growth) }\end{array}$} \\
\hline
\end{tabular}

Table7 explains that $81 \%$ of the variation in the GDP growth of India is explained together by household final consumption expenditure per capita growth and gross capital formation. The coefficient table explains the change in the dependent variable for a unit change in the independent variable. Table 8 explains the result:

TABLE 8

COEFFICIENTS $^{\mathrm{a}}$

\begin{tabular}{|c|c|c|c|c|c|c|c|c|}
\hline \multirow{2}{*}{\multicolumn{2}{|c|}{ Model }} & \multicolumn{2}{|c|}{$\begin{array}{l}\text { Unstandardized } \\
\text { Coefficients }\end{array}$} & \multirow{2}{*}{$\begin{array}{l}\text { Standardized } \\
\text { Coefficients } \\
\text { Beta }\end{array}$} & \multirow[b]{2}{*}{$\mathrm{t}$} & \multirow[b]{2}{*}{ Sig. } & \multicolumn{2}{|c|}{$\begin{array}{l}95 \% \\
\text { Confidence } \\
\text { Interval for B }\end{array}$} \\
\hline & & B & \begin{tabular}{|l|} 
Std. \\
Error
\end{tabular} & & & & $\begin{array}{l}\text { Lower } \\
\text { Bound }\end{array}$ & $\begin{array}{l}\text { Upper } \\
\text { Bound }\end{array}$ \\
\hline \multirow[t]{2}{*}{1} & (Constant) & 3.549 & .645 & & 5.502 & .000 & 2.220 & 4.877 \\
\hline & $\begin{array}{l}\text { IND Household final consumption } \\
\text { expenditure per capita growth } \\
(\text { annual \%) }\end{array}$ & .698 & .131 & .728 & 5.310 & .000 & .427 & .969 \\
\hline \multirow[t]{3}{*}{2} & (Constant) & 2.791 & .411 & & 6.791 & .000 & 1.943 & 3.639 \\
\hline & $\begin{array}{l}\text { IND Household final consumption } \\
\text { expenditure per capita growth } \\
\text { (annual \%) }\end{array}$ & .634 & .081 & .661 & 7.832 & .000 & .467 & .802 \\
\hline & $\begin{array}{l}\text { IND Gross capital formation (annual } \\
\% \text { growth) }\end{array}$ & .123 & .019 & .553 & 6.546 & .000 & .084 & .161 \\
\hline
\end{tabular}

The $\beta$ coefficients of household final consumption expenditure per capita growth and gross capital formation are 0.634 and 0.0123 respectively. It reflects that the GDP growth of India would increase by $63 \%$ and $1 \%$ respectively due to one unit increase in these two components.

\section{Analysis of Economic Indicators: Case of CHINA}

China's GDP growth has a statistically significant and positive association with its foreign direct investment, net inflows with a coefficient of 0.667. It has significant moderate association with consumption of fixed capital, gross capital formation and household final consumption expenditure with a coefficient of $0.428,0.326$ and 0.395 . Stepwise regression identifies the significant determinants of economic growth. Table -9 explains the result: 
TABLE 9

MODEL SUMMARY

\begin{tabular}{|c|c|c|c|c|c|c|c|c|c|}
\hline \multirow[b]{2}{*}{ Model } & \multirow[b]{2}{*}{$\mathrm{R}$} & \multirow[b]{2}{*}{$\begin{array}{l}\text { R } \\
\text { Square }\end{array}$} & \multirow[b]{2}{*}{$\begin{array}{l}\text { Adjusted } \\
\text { R Square }\end{array}$} & \multirow[b]{2}{*}{$\begin{array}{l}\text { Std. Error of } \\
\text { the Estimate }\end{array}$} & \multicolumn{5}{|c|}{ Change Statistics } \\
\hline & & & & & $\begin{array}{l}\text { R Square } \\
\text { Change }\end{array}$ & F Change & df1 & df2 & $\begin{array}{l}\text { Sig. F } \\
\text { Change }\end{array}$ \\
\hline 1 & $.667^{\mathrm{a}}$ & .444 & .422 & 1.88156 & .444 & 20.004 & 1 & 26 & .000 \\
\hline 2 & $.791^{\mathrm{b}}$ & .626 & .594 & 1.57635 & .181 & 11.618 & 1 & 25 & .002 \\
\hline 3 & $.862^{\mathrm{c}}$ & .743 & .710 & \begin{tabular}{|l|}
1.33309 \\
\end{tabular} & .118 & 10.558 & 1 & 24 & .004 \\
\hline \multirow{2}{*}{\multicolumn{10}{|c|}{$\begin{array}{l}\text { a. Predictors: (Constant), CHN Foreign direct investment, net inflows (\% of GDP) } \\
\text { b. Predictors: (Constant), CHN Foreign direct investment, net inflows ( } \% \text { of GDP), CHN Gross capital } \\
\text { formation (annual \% growth) }\end{array}$}} \\
\hline & & & & & & & & & \\
\hline \multicolumn{10}{|c|}{$\begin{array}{l}\text { c. Predictors: (Constant), CHN Foreign direct investment, net inflows (\% of GDP), CHN Gross capital } \\
\text { formation (annual \% growth), CHN Gross savings ( } \% \text { of GDP) }\end{array}$} \\
\hline
\end{tabular}

Table -9 depicts that foreign direct investment; net inflows, gross capital formation and gross savings explain $71 \%$ of variation in the GDP growth of China. The $\beta$ coefficients has high explanatory power in the regression model. The result is as follows:

\section{TABLE 10 COEFFICIENTS}

\begin{tabular}{|c|c|c|c|c|c|c|c|c|}
\hline \multirow{2}{*}{\multicolumn{2}{|c|}{ Model }} & \multicolumn{2}{|c|}{$\begin{array}{l}\text { Unstandardized } \\
\text { Coefficients }\end{array}$} & \multirow{2}{*}{$\begin{array}{l}\text { Standardized } \\
\text { Coefficients } \\
\text { Beta }\end{array}$} & \multirow[t]{2}{*}{$\mathrm{T}$} & \multirow[t]{2}{*}{ Sig. } & \multicolumn{2}{|c|}{$\begin{array}{l}95.0 \% \text { Confidence } \\
\text { Interval for B }\end{array}$} \\
\hline & & B & \begin{tabular}{|l} 
Std. \\
Error
\end{tabular} & & & & $\begin{array}{l}\text { Lower } \\
\text { Bound }\end{array}$ & $\begin{array}{l}\text { Upper } \\
\text { Bound }\end{array}$ \\
\hline \multirow[t]{2}{*}{1} & (Constant) & 5.046 & 1.088 & & 4.64 & .000 & 2.805 & 7.287 \\
\hline & $\begin{array}{l}\text { CHN Foreign direct } \\
\text { investment, net inflows (\% of } \\
\text { GDP) }\end{array}$ & 1.291 & .289 & .667 & 4.47 & .000 & .697 & 1.886 \\
\hline \multirow[t]{3}{*}{2} & (Constant) & 3.308 & 1.044 & & 3.17 & .004 & 1.152 & 5.463 \\
\hline & $\begin{array}{l}\text { CHN Foreign direct } \\
\text { investment, net inflows (\% of } \\
\text { GDP) }\end{array}$ & .410 & .244 & .728 & 5.77 & .000 & .905 & 1.914 \\
\hline & $\begin{array}{l}\text { CHN Gross capital formation } \\
\text { (annual \% growth) }\end{array}$ & .070 & .020 & .430 & 3.41 & .002 & .027 & .112 \\
\hline \multirow[t]{4}{*}{3} & (Constant) & -.609 & 2.592 & & -1.78 & .089 & -9.971 & .752 \\
\hline & $\begin{array}{l}\text { CHN Foreign direct } \\
\text { investment, net inflows (\% of } \\
\text { GDP) }\end{array}$ & .452 & .207 & .750 & 7.01 & .000 & 1.023 & 1.880 \\
\hline & $\begin{array}{l}\text { CHN Gross capital formation } \\
\text { (annual \% growth) }\end{array}$ & .084 & .018 & .521 & 4.72 & .000 & .047 & .121 \\
\hline & $\begin{array}{l}\text { CHN Gross savings ( } \% \text { of } \\
\text { GDP) }\end{array}$ & .168 & .052 & .355 & 3.25 & .004 & .061 & .275 \\
\hline
\end{tabular}

It is very clear from Table-10 that China's GDP growth is significantly dependent on its net inflows of foreign direct investment, gross savings and gross capital formation. It is statistically significant as pvalue for these three variables is less than $\alpha=0.05$. This result indicates that for one unit increase in the $\beta$ 
coefficient of these three variables, the GDP growth of China would increase by $45 \%, 8 \%$ and $16 \%$ respectively.

\section{Analysis of Economic Indicators: Case of SOUTH AFRICA}

The association between the economic indicators are investigated using correlation analysis. The result shows that South Africa's GDP has strong positive association with its gross capital formation, final consumption expenditure and household final consumption expenditure with a coefficient of 0.701 , 0.883 and 0.878 respectively. This output is statistically significant at $5 \%$ level of significance. The stepwise regression output is as follows:

\section{TABLE 11 MODEL SUMMARY}

\begin{tabular}{|c|c|c|c|c|c|c|c|c|c|}
\hline \multirow[b]{2}{*}{ Model } & \multirow[b]{2}{*}{$\mathrm{R}$} & \multirow[b]{2}{*}{$\begin{array}{l}\mathrm{R} \\
\text { Square }\end{array}$} & \multirow[b]{2}{*}{$\begin{array}{l}\text { Adjusted } \\
\text { R Square }\end{array}$} & \multirow{2}{*}{$\begin{array}{l}\text { Std. Error } \\
\text { of the } \\
\text { Estimate }\end{array}$} & \multicolumn{5}{|c|}{ Change Statistics } \\
\hline & & & & & $\begin{array}{l}\text { R Square } \\
\text { Change }\end{array}$ & F Change & df1 & df2 & $\begin{array}{l}\text { Sig. F } \\
\text { Change }\end{array}$ \\
\hline 1 & $.883^{\mathrm{a}}$ & .779 & .770 & .98650 & .779 & 88.103 & 1 & 27 & .000 \\
\hline 2 & $.918^{\mathrm{b}}$ & .843 & .830 & .84779 & .064 & 9.850 & 1 & 25 & .004 \\
\hline 3 & $.938^{\mathrm{c}}$ & .880 & .864 & .75935 & .036 & 6.916 & 1 & 24 & .015 \\
\hline \multicolumn{10}{|c|}{$\begin{array}{l}\text { a. Predictors: (Constant), SA Final consumption expenditure, etc. (annual \% growth) } \\
\text { b. Predictors: (Constant), SA Final consumption expenditure, etc. (annual \% growth), SA Household } \\
\text { final consumption expenditure (annual } \% \text { growth) }\end{array}$} \\
\hline
\end{tabular}

The result shows that final consumption expenditure, household final consumption expenditure and gross savings are the significant determinants of GDP growth in South Africa. These variables contribute $86 \%$ variability in explaining the GDP growth. The $\beta$ values explains the following:

TABLE 12

COEFFICIENTS SOUTH AFRICA

\begin{tabular}{|c|c|c|c|c|c|c|c|c|}
\hline & & \multicolumn{2}{|c|}{$\begin{array}{l}\text { Unstandardized } \\
\text { Coefficients }\end{array}$} & \multirow{2}{*}{$\begin{array}{l}\text { Standardized } \\
\text { Coefficients } \\
\text { Beta }\end{array}$} & \multirow[t]{2}{*}{$\mathrm{T}$} & \multirow[t]{2}{*}{ Sig. } & \multicolumn{2}{|c|}{$\begin{array}{l}95.0 \% \\
\text { Confidence } \\
\text { Interval for B }\end{array}$} \\
\hline \multicolumn{2}{|c|}{ Model } & B & $\begin{array}{l}\text { Std. } \\
\text { Error }\end{array}$ & & & & $\begin{array}{l}\text { Lower } \\
\text { Bound }\end{array}$ & $\begin{array}{l}\text { Upper } \\
\text { Bound }\end{array}$ \\
\hline \multirow[t]{2}{*}{1} & (Constant) & .404 & .283 & & 1.427 & .166 & -.179 & .988 \\
\hline & $\begin{array}{l}\text { Final consumption expenditure } \\
\text { (annual \% growth) }\end{array}$ & .772 & .082 & .883 & 9.386 & .000 & .603 & .942 \\
\hline \multirow[t]{3}{*}{2} & (Constant) & .138 & .258 & & .534 & .599 & -.395 & .670 \\
\hline & $\begin{array}{l}\text { Final consumption expenditure } \\
\text { (annual \% growth) }\end{array}$ & .432 & .129 & .494 & 3.336 & .003 & .165 & .699 \\
\hline & $\begin{array}{l}\text { Household final consumption } \\
\text { expenditure (annual \% growth) }\end{array}$ & .375 & .119 & .464 & 3.138 & .004 & .128 & .621 \\
\hline \multirow[t]{4}{*}{3} & (Constant) & 5.510 & 2.056 & & 2.680 & .013 & 1.257 & 9.763 \\
\hline & $\begin{array}{l}\text { Final consumption expenditure } \\
\text { (annual \% growth) }\end{array}$ & .376 & .118 & .429 & 3.185 & .004 & .132 & .620 \\
\hline & $\begin{array}{l}\text { Household final consumption } \\
\text { expenditure (annual \% growth) }\end{array}$ & .354 & .107 & .439 & 3.303 & .003 & .132 & .576 \\
\hline & Gross savings ( $\%$ of GDP) & -.307 & .117 & -.209 & -2.63 & .015 & -.548 & -.065 \\
\hline
\end{tabular}


Table-12 depicts that the final consumption expenditure, household final consumption expenditure, and gross savings explain the GDP growth of South Africa. These variables are statistically significant as their $p$-values are $0.004,0.003$. The result also shows that the $\beta$ coefficients for these variables are 0.376 , 0.354 and -0.307 respectively. This has high explanatory power. It signifies that for one unit change in final consumption expenditure and household final consumption expenditure, the GDP growth would increase by $37 \%$ and $35 \%$ respectively whereas for one unit increase in the gross saving, the GDP growth of South Africa would decrease by $30 \%$.

\section{CONCLUSION AND IMPLICATIONS}

This research paper has examined the determinants of GDP growth of BRICS countries. We used the secondary data from the investment report 2018 and the world development indicators 2018 of World Bank publication. We consider twenty economic indicators in this study such as GDP growth, fixed capital formation ( $\%$ of GDP), Stocks traded, total value (\% of GDP), adjusted savings: consumption of fixed capital ( $\%$ of GNI), gross capital formation ( $\%$ of GDP), domestic credit to private sector by banks (\% of GDP), gross capital formation (annual \% growth), final consumption expenditure (annual \% growth), domestic credit to private sector by banks ( $\%$ of GDP), general government final consumption expenditure (annual \% growth), household final consumption expenditure (annual \% growth), foreign direct investment, net inflows (\% of GDP), gross savings ( $\%$ of GDP), gross domestic savings (\% of GDP). Stepwise regression is used to identify the significant economic indicators of GDP growth of the BRICS countries. The models employed revealed that the most common economic indicator across BRICS countries is gross capital formation followed by consumption expenditure. FDI growth is one of the key economic indicator only for China. For countries like India, Brazil, Russia and South Africa, FDI inflow is insignificant indicator of GDP growth.

The result of this study indicates that to increase the GDP growth Brazil should focus more on the final consumption \& expenditure, gross capital formation \& general government final consumption expenditure. For Russia to increase the GDP growth, it should frame the policies to boost general government final consumption expenditure \& reduce the gross capital formation. In INDIA, the GDP growth has increased significantly due to the gross capital formation \& Household final consumption expenditure. Therefore, it should focus more on these two factors instead of struggling continuously to increase the FDI inflow. Whereas for CHINA to increase the GDP growth, it should focus more on the FDI, gross capital formation \& discourage gross savings. South Africa should focus more on the growth of consumption expenditure and reduction of the gross savings to increase the GDP growth \& should. Therefore, policies in South Africa should be designed to encourage consumption \& to discourage savings. The only factor common for all the five economies is the consumption expenditure. Therefore, to improve consumption expenditure, the other economic factors serving as the determinants to consumption expenditure are also to be improved.

The focus of the countries is to improve the economic growth as a developed country can promote the socio-economic development. This study found discrepancy in the economic indicators amongst all the BRICS countries. Therefore, each of these countries shall focus on their respective economic indicators to achieve maximum growth. This study is very useful for policy makers and investors.

\section{ENDNOTES}

1. https://unctad.org/en/PublicationsLibrary/wir2018_en.pdf

2. https://www.imf.org/external/datamapper/PPPSH@WEO/OEMDC/ADVEC/WEOWORLD

3. https://unctadstat.unctad.org/wds/TableViewer/tableView.aspx

4. https://ged-project.de/ged-blog/improving-public-understanding-of-economic-globalisation/globalizationreport-2018-what-about-the-brics-countries/

5. https://unctad.org/en/PublicationsLibrary/wir2018_en.pdf

6. http://datatopics.worldbank.org/world-development-indicators/ 
7. Appendix Table 1

8. Appendix Table 3

9. Appendix Table 4

10. Appendix Table 5

\section{REFERENCES}

Ahluwalia, M. (2001, March). State Level Performance under Economic Reforms in India (Centre for Research on Economic Development and Policy Reform. Working Paper No. 96, 71.

Alam M. S. (2000). FDI and Economic Growth of India and Bangladesh: A comparative study. Indian Journal of Economics, lxxx, part 1(316), 1-15. BRICS and MINT countries. AGDI working paper. WP/18/038. Retrieved from http://ssrn.com/abtract $=3266224$

Ali, A.S. (2015). Stock market development and economic growth: An empirical analysis between Turkey and BRICS countries. Springer International publishing Switzerland, Chapter-24, DOI: 10.1007/978-3-319-09710-7 24

Asongu, S.A., Akpan, U.S., \& Isihak, S.R. (2018). Determinants of foreign direct investment in fast growing economies.

Billington N. (1999). The Location of Foreign Direct Investment: An Empirical Analysis. Applied Economics, 31, 65-76.

Bose, S., \& Kohli, B. (2018). Study of FDI trends and patterns in BRICS economies during the period 1990-2015. Emerging Economy Studies, 4(1), 78-101.

Cheng, L., \& Kwan, Y. (2000). What are the Determinants of the Location of Foreign Direct Investment? The Chinese Experience. Journal of International Economics, 51, 379-400.

Feenstra, R. C., \& Markusen, J. R. (1992). Accounting for Growth with New Inputs. NBER Working Paper, No. 4114.

Hanson, G. (2001). Should Countries Promote Foreign Direct Investment? G-24 Discussion Papers 9. United Nations Conference on Trade and Development.

Head, T.C., \& Sorensen, P.F. (2005). Attracting Foreign Direct Investment: The Potential Role of National Culture. The Journal of American Academy of Business, 6(1), 305-308.

Kamath, G.B. (2009, September-December). Macroeconomic Determinants of Foreign Direct Investment in India. Baudhik, 1(2), 3-13.

Keynes, J.M. (2007). The General Theory of Employment, Interest and Money. Basingstoke, Hampshire: Palgrave Macmillan. ISBN 0-230-00476-8.

Khetsi, Q.S., \& Mongale, I.P. (2015). The impact of capital markets on the economic growth in South Africa. Journal of Goverance and Regulation, 4(1).

Kravis, I.B., \& Lipsey, R. (1982). Location of Overseas Production and Production for Exports by US Multinational Firms. Journal of International Economics, 12, 201-223.

Kumar, N., \& Pradhan, J.P. (2002). Foreign Direct Investment, Externalities and Economic Growth in Developing Countries: Some Empirical Explorations and Implications for WTO Negotiations on Investment. RIS Discussion Papers 27. Research and Information System for the Non- Aligned and Other Developing Countries, New Delhi.

Kwang, J., \& Singh, H. (1996). The Determinants of Foreign Direct Investment in Developing Countries. Transnational Corporations, 5(2), 67-105.

Lenee, T.L., \& Oki, J. (2017). Capital market development and economic growth: Evidence from the MINT countries. Journal of Economics and Sustainable Development. ISSN 2222-1700, 8(2).

Mercan, M., \& Gocer, I. (2013). The effect of financial development on economic growth in BRIC-T countries: Panel data analysis. Journal of Economic and Social Studies, 3(1).

Osaseri, G., \& Osamwongi, I.O. (2019). Impact of stock market development on economic growth in BRICS. International Journal of Financial Research, 10(1).

Panigrahi, T., \& Mall, S. (2017). India's Competitive Position amongst the Asian Economies: An Empirical Study on FDI Inflow. European Journal of Finance and Banking Research, 7(7), 1-23 
Panigrahi, T., Patra, R., \& Satapathy, S. (2015). Distribution of Foreign Direct Investment in Indian Regions: A Trend Analysis. Researchgate, 4(2),157-171. https://doi.org/10.15410/aijm\%2F2015\%2Fv4i2\%2F67726

Peacock, A. (1992). Public Choice Analysis in Historical Perspective. Cambridge University Press, p. 60.

Singh, G., \& Paul, J. (2014, April 29). Foreign Direct Investment in India - Trends, Pattern and Linkage. SMART: Journal of Business Management, 10(1). Retrieved from SSRN: http://ssrn.com/abstract=2430931

Wheeler, D., \& Mody, A. (1992). International Investment Location Decisions: The case of U.S. firms. Journal of International Economics, 33, 57-76.

World Bank Report. (2017). World Investment Report.

Yakhou, M., \& Dorweiler, V.P. (2006). Business international: An analysis of the international market. The Journal of American Academy of Business, 8(2), 186-189. 


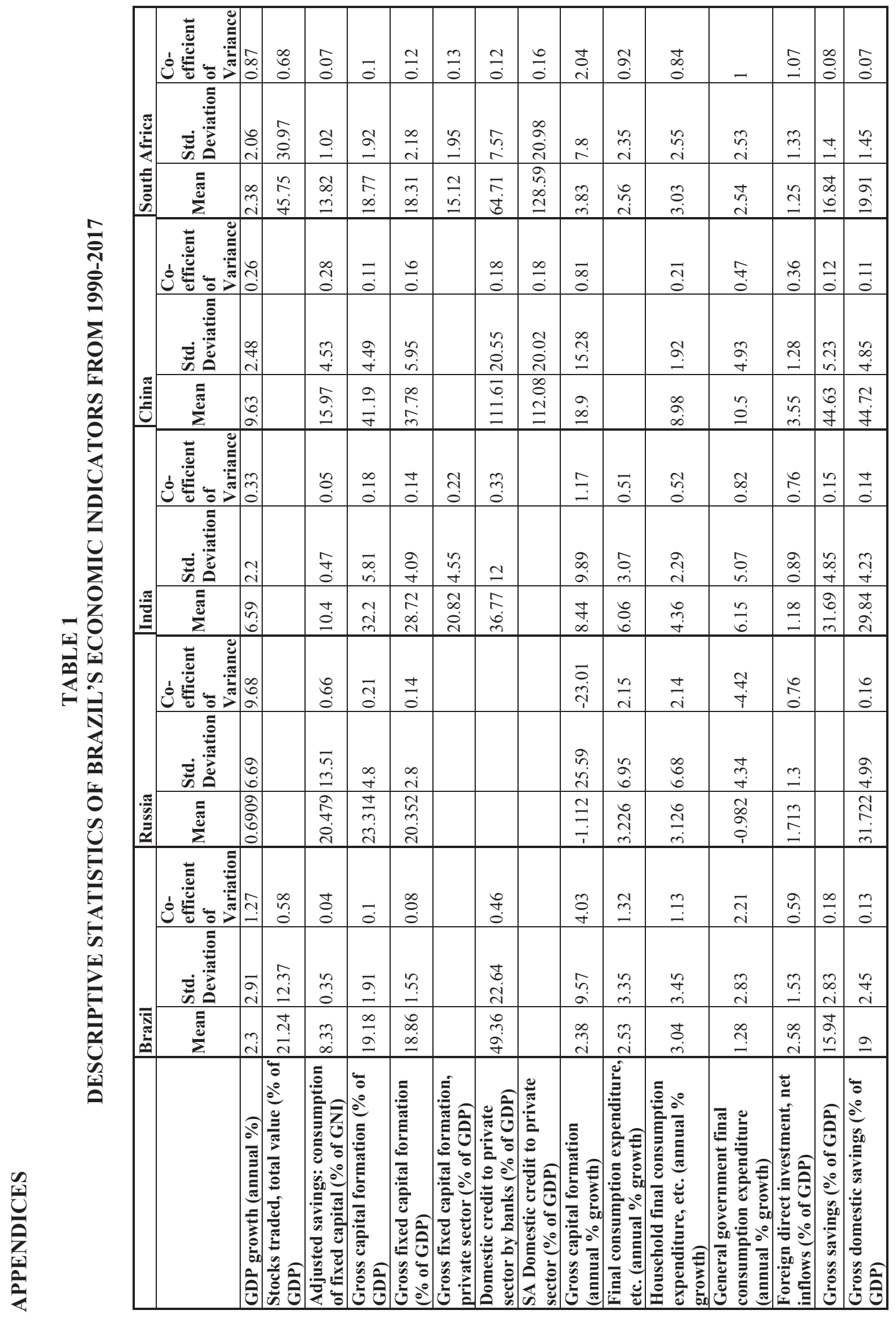

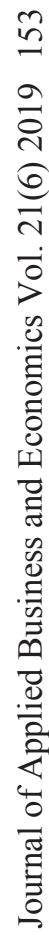




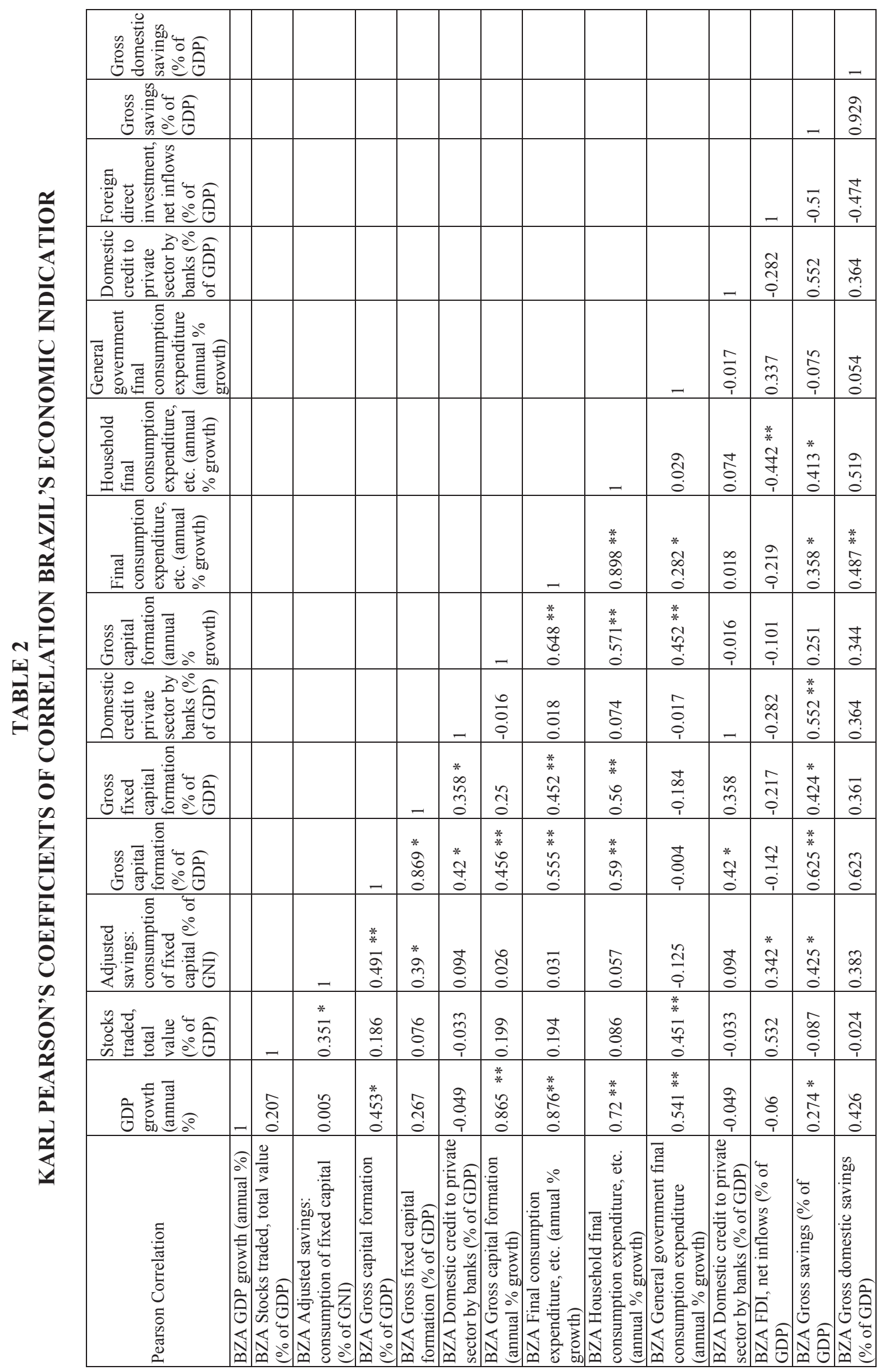

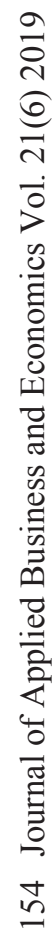




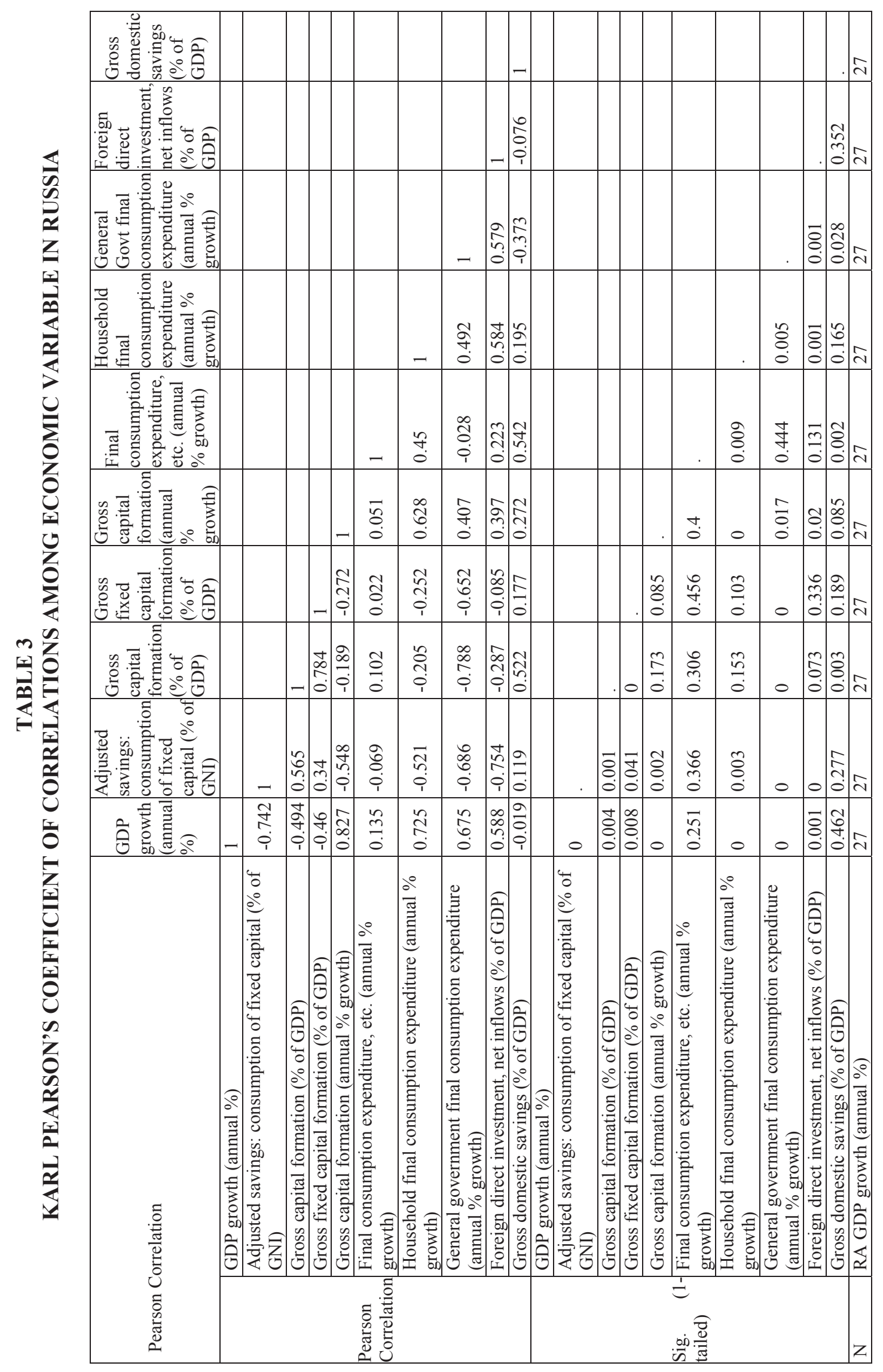

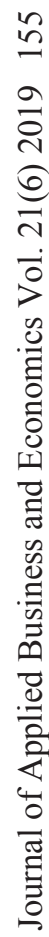




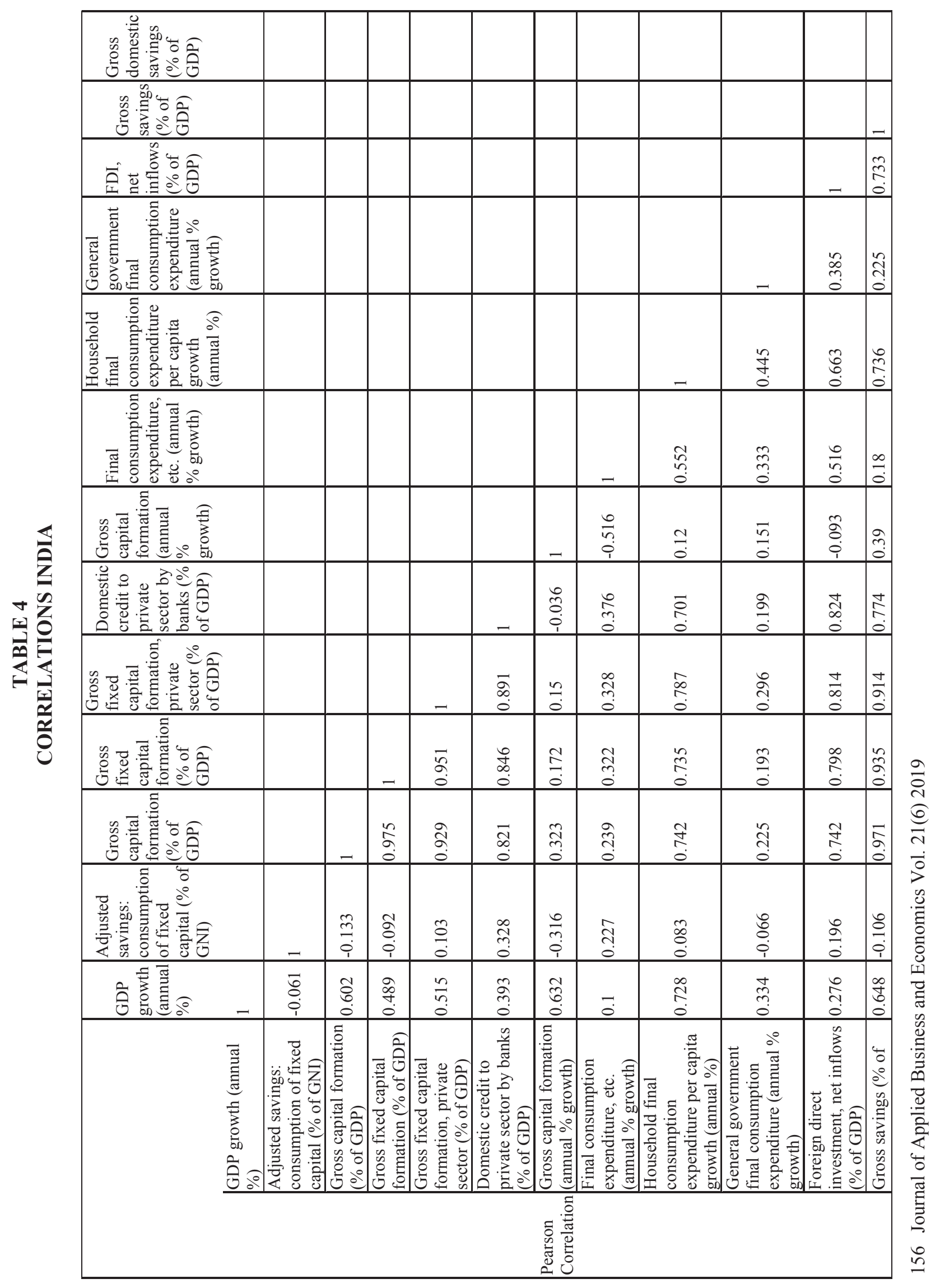




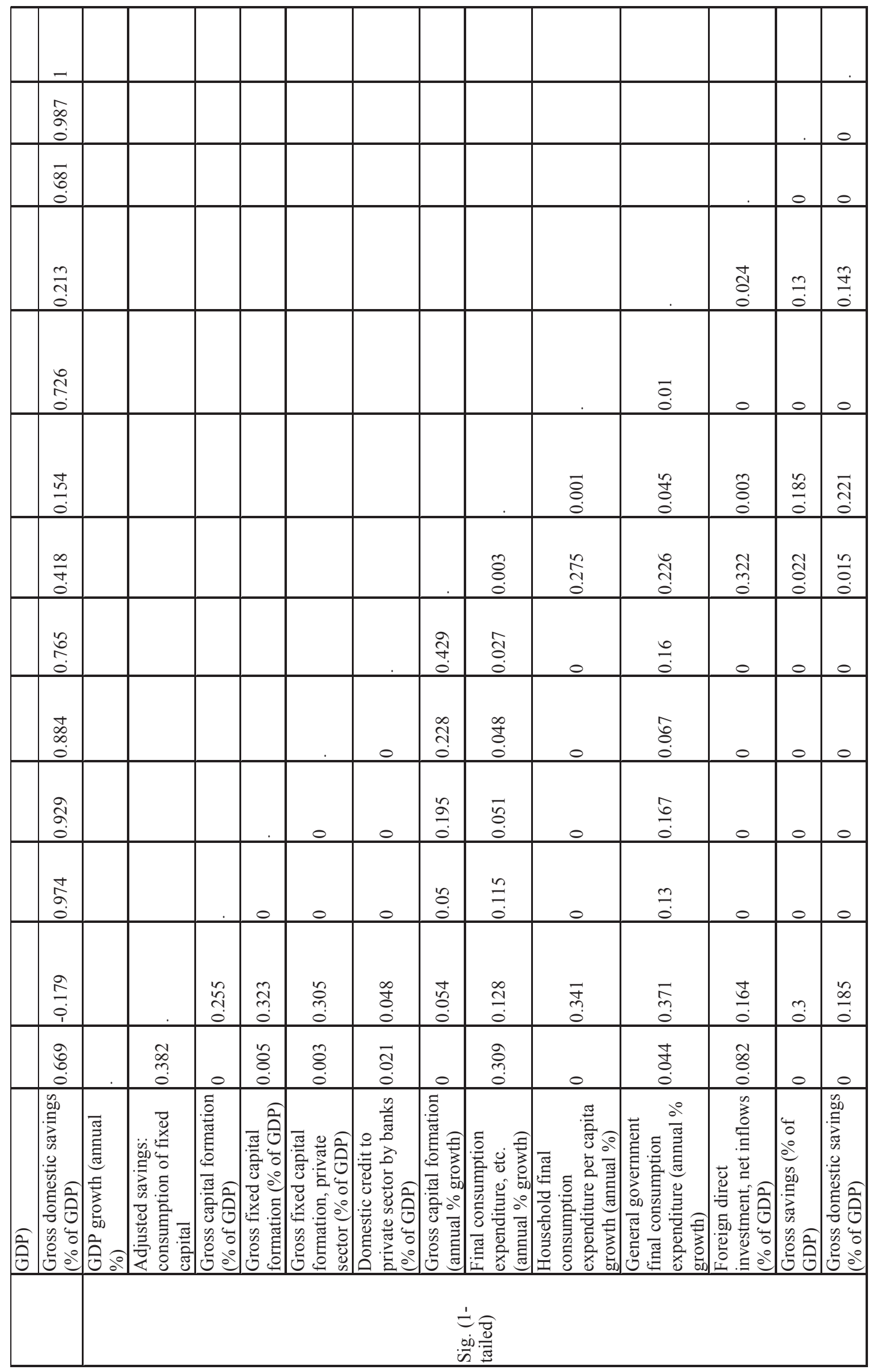




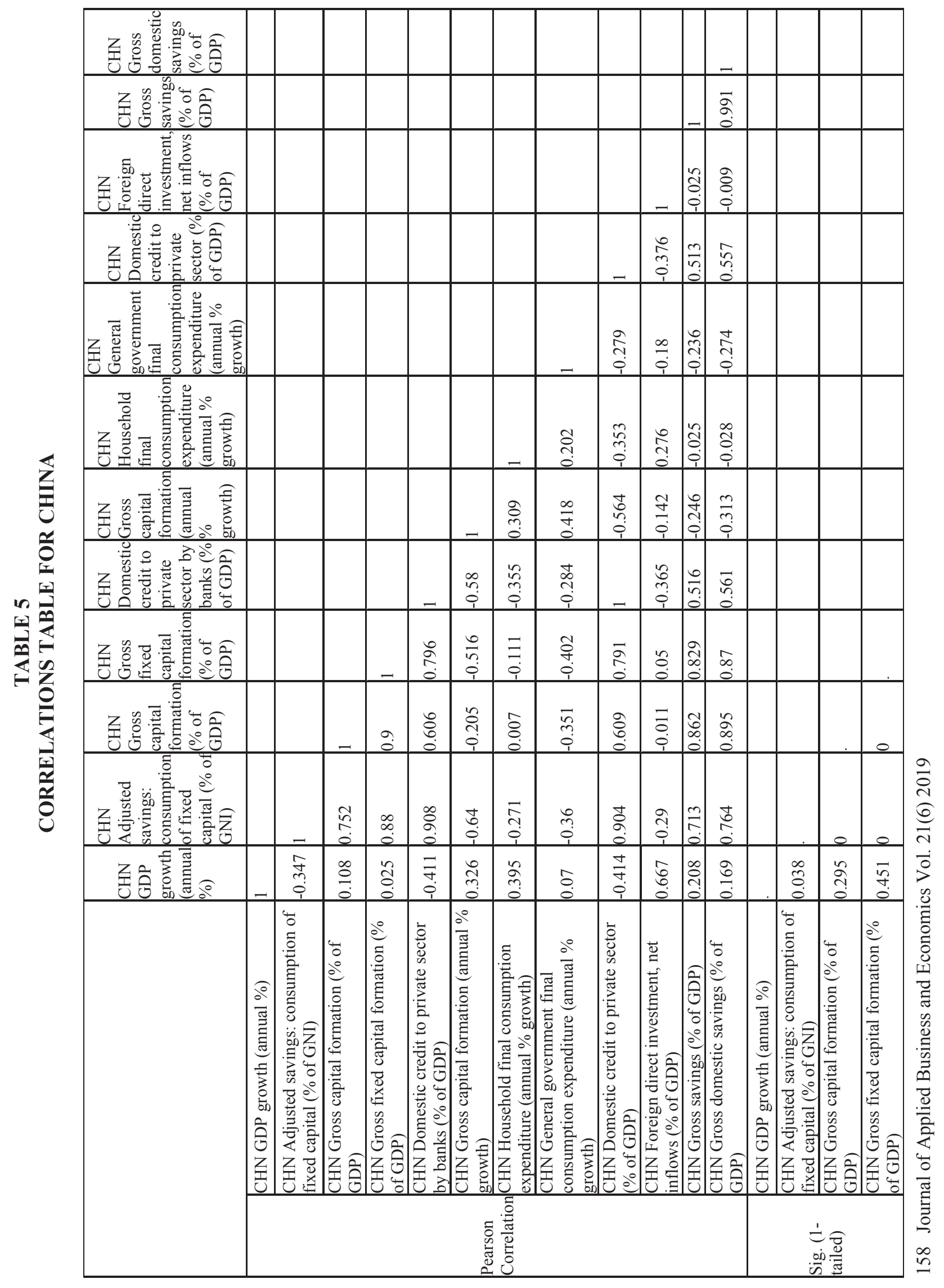



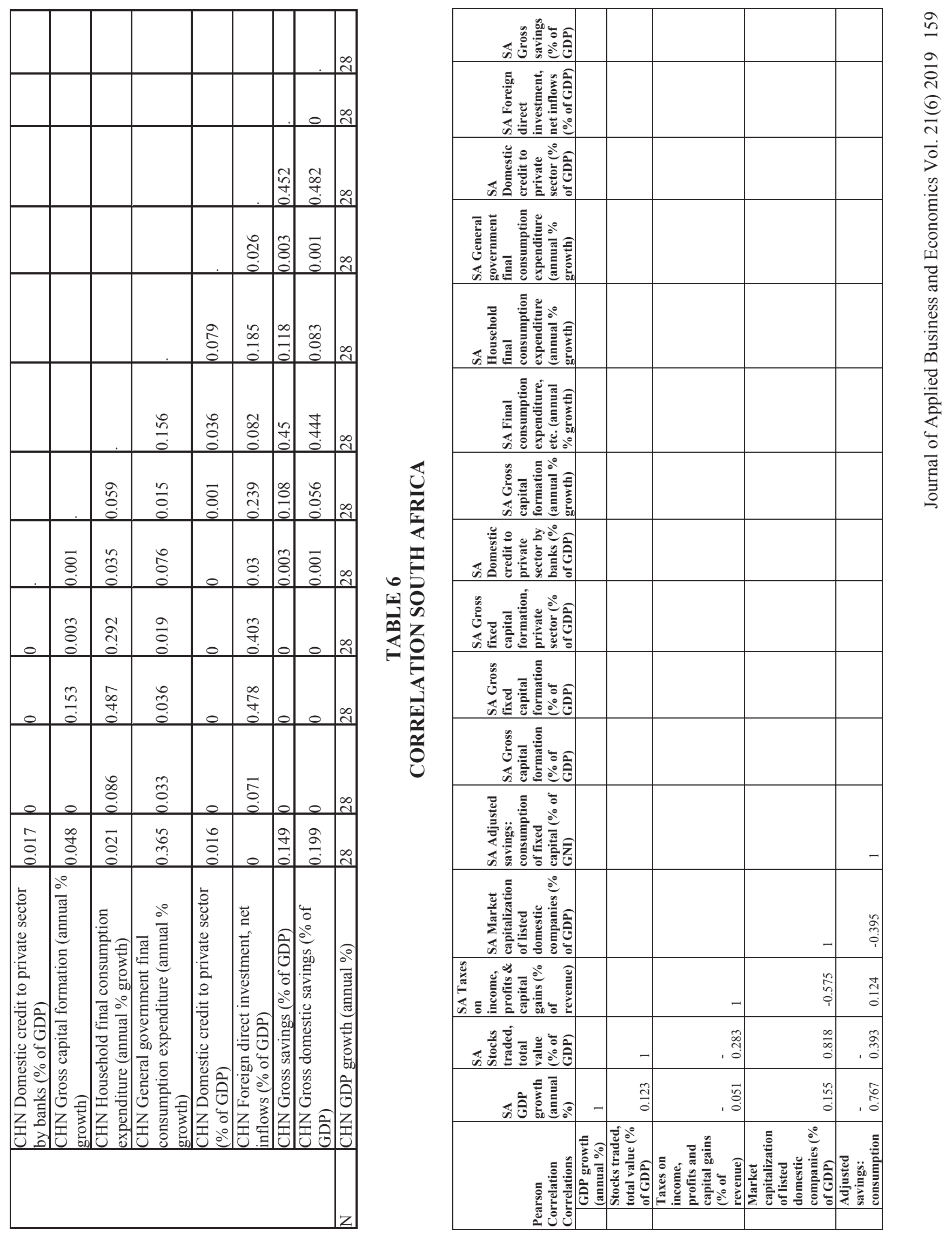


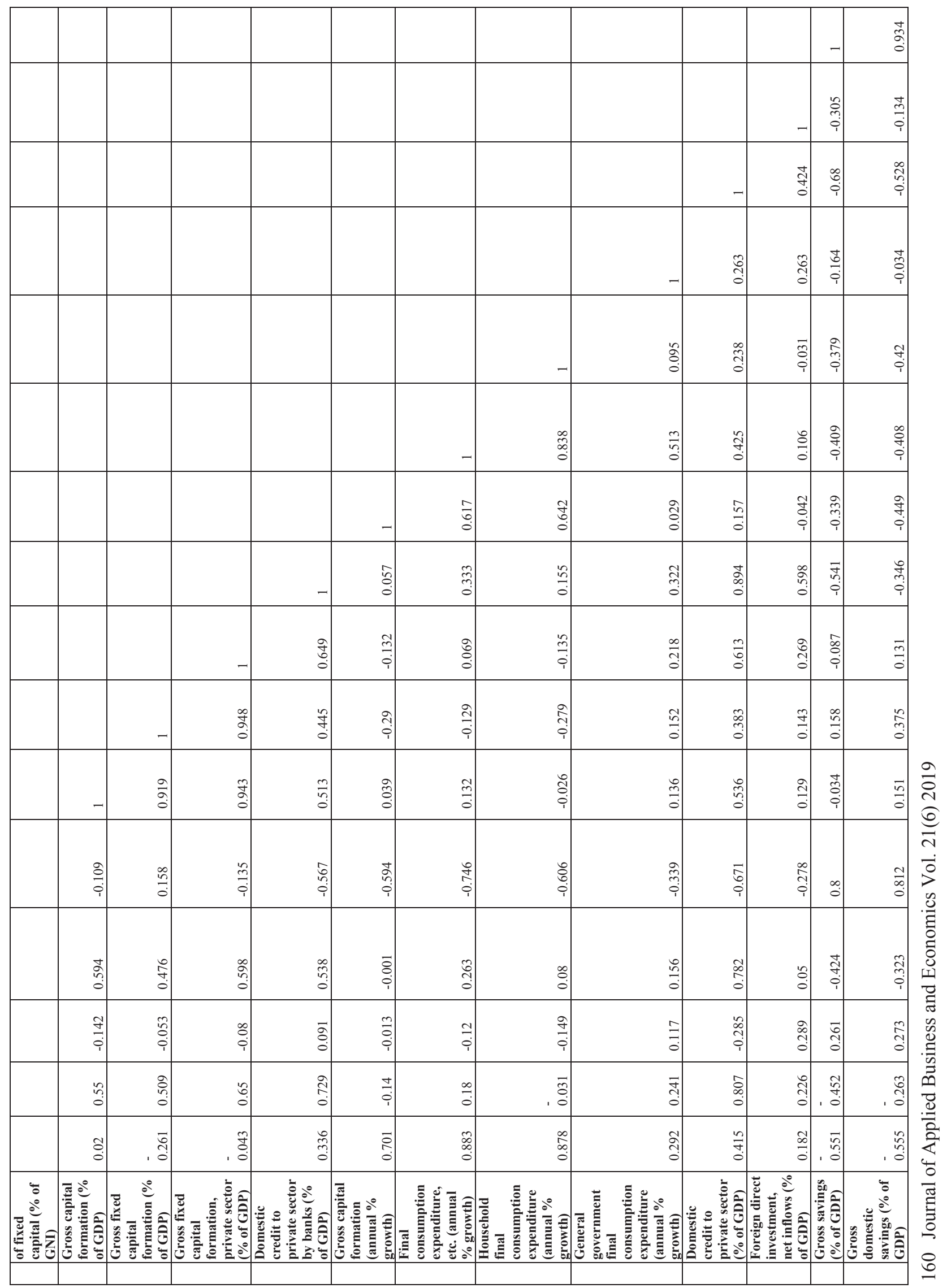




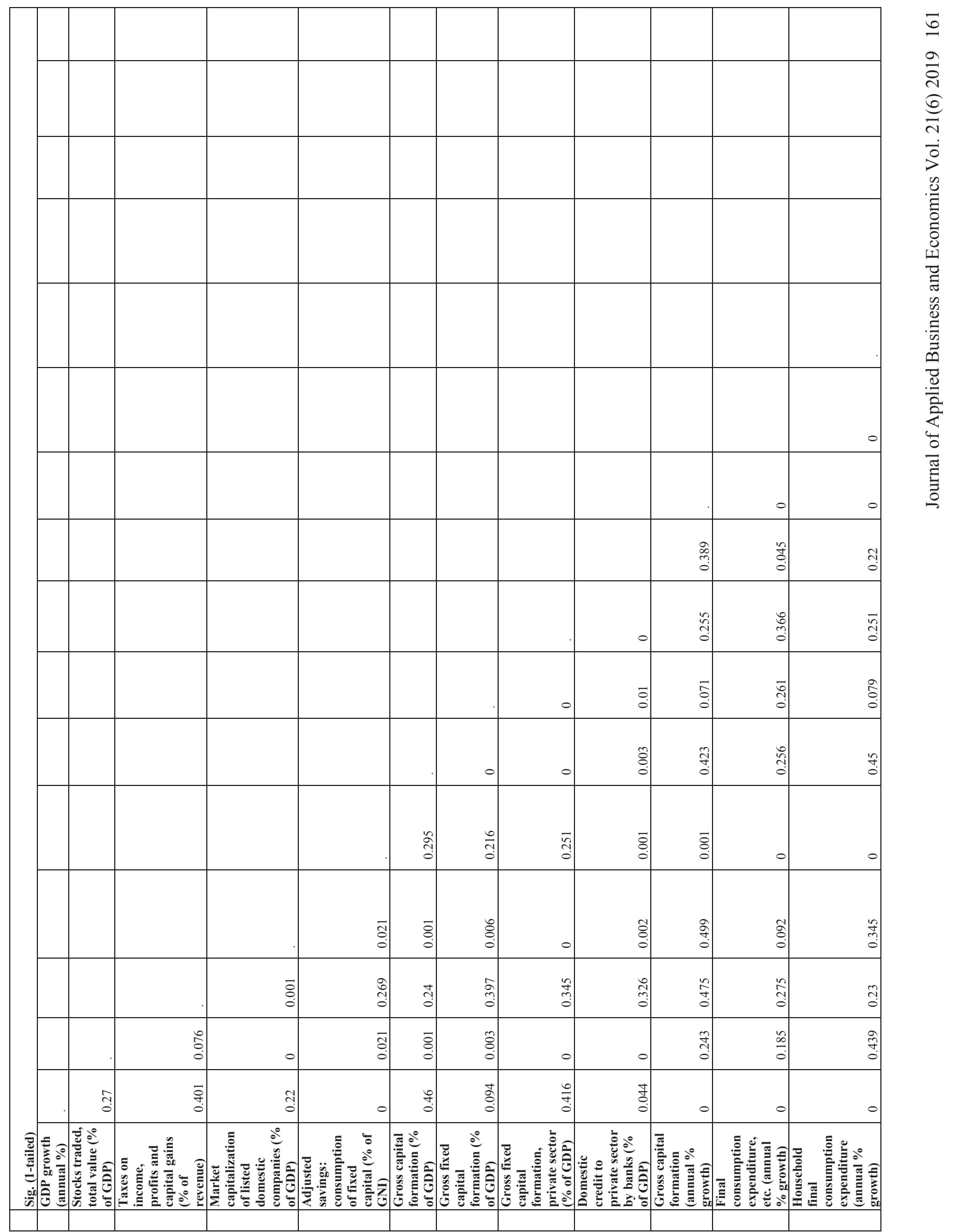




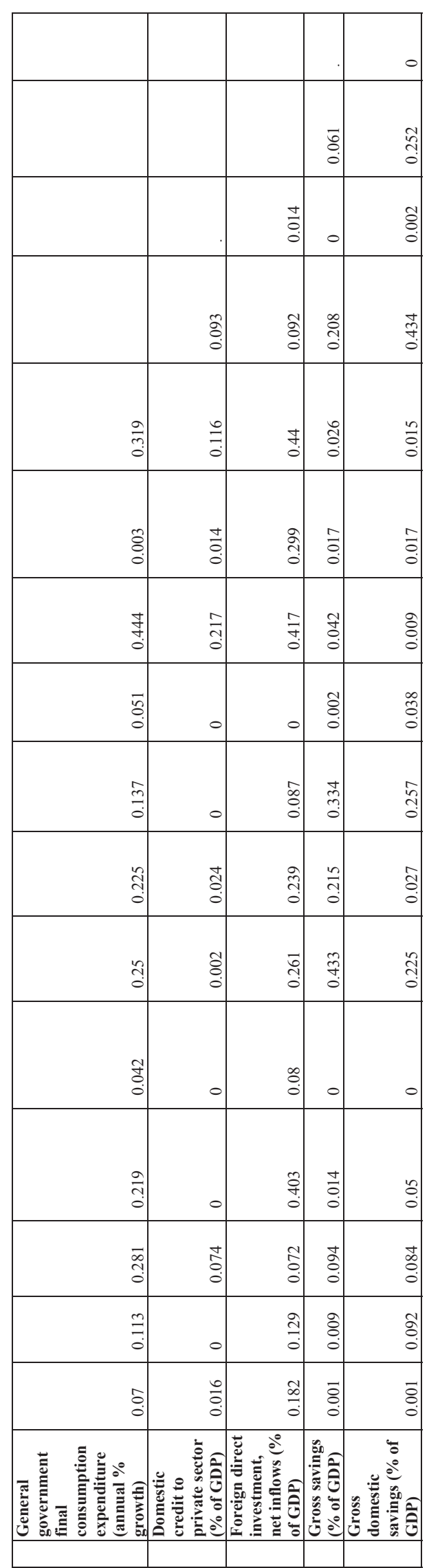

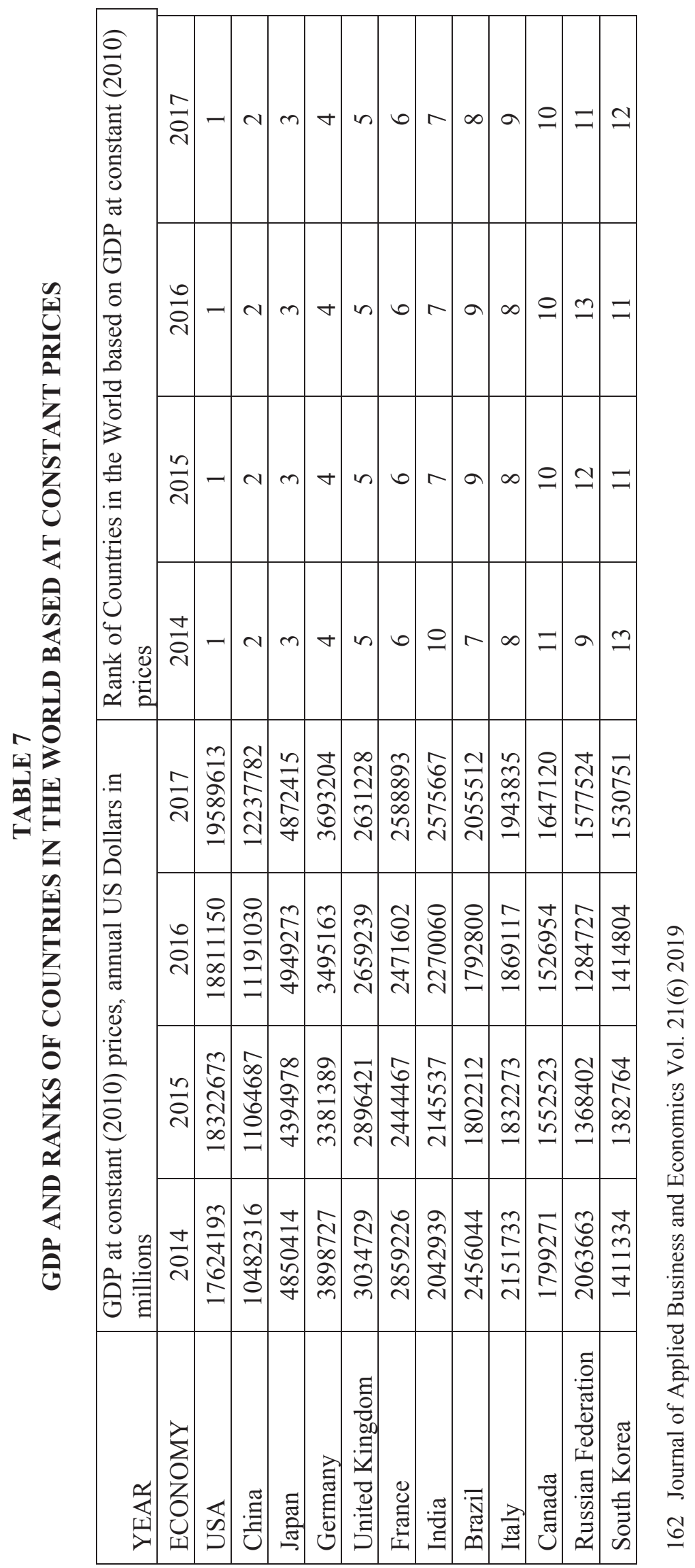


๓

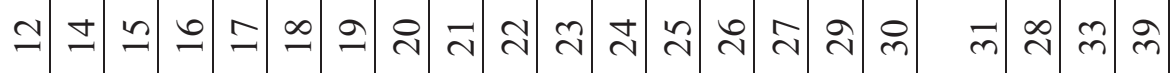

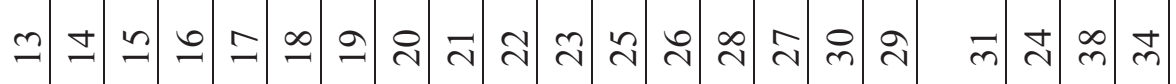

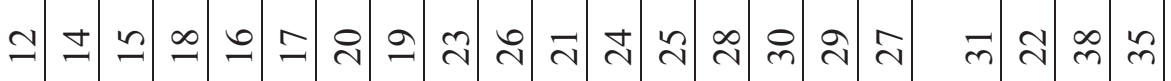

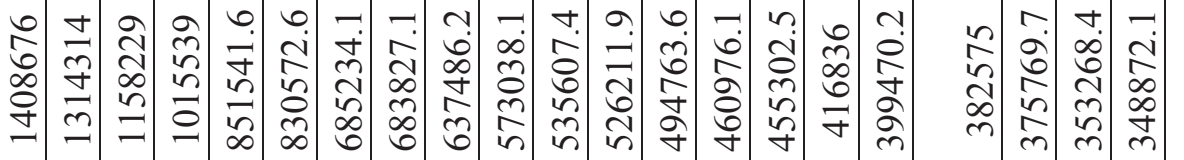

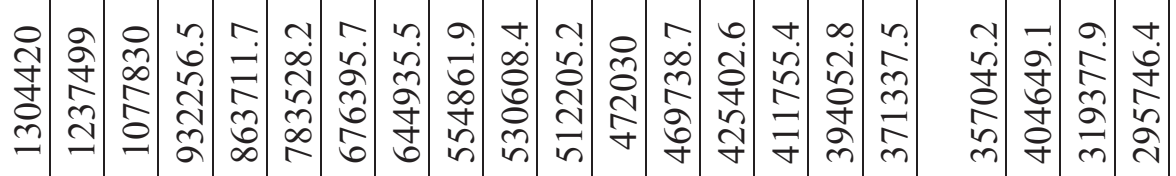

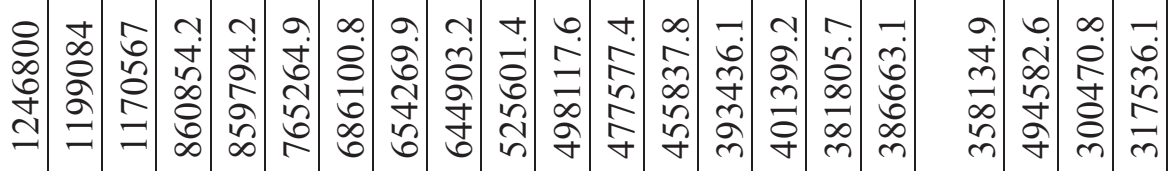

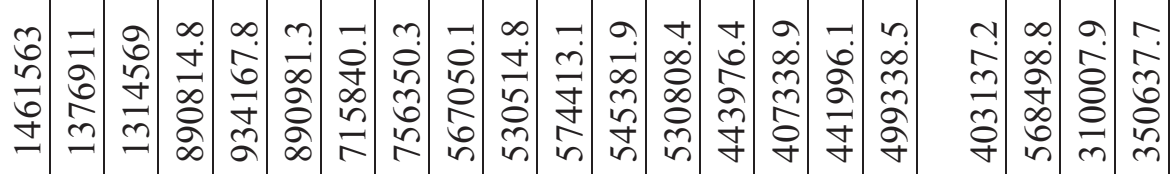

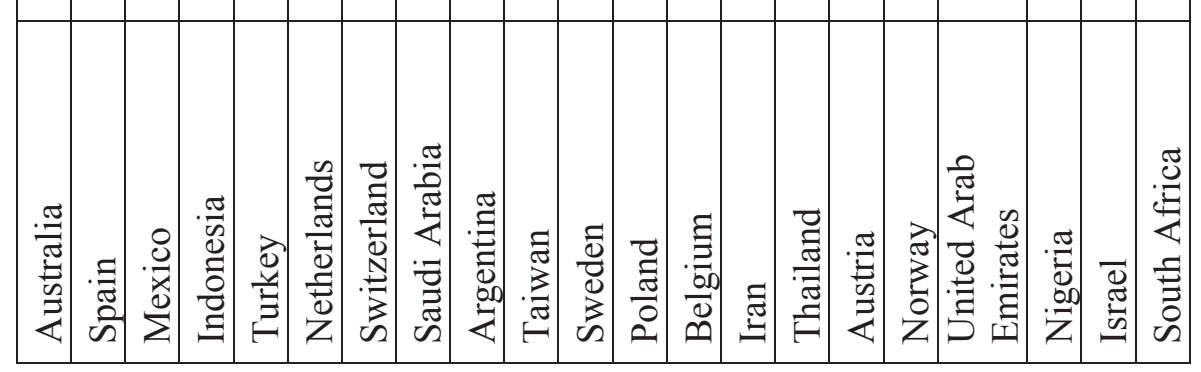

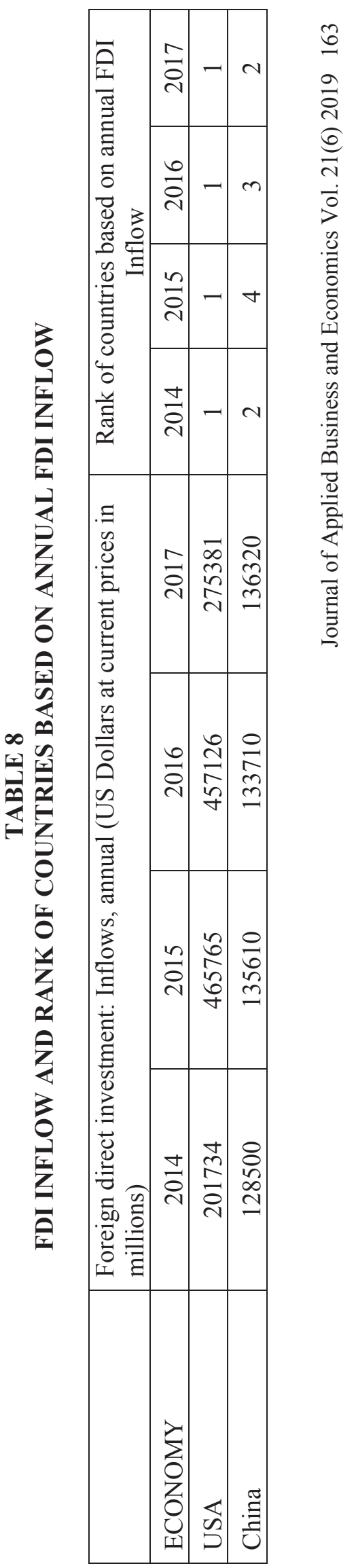




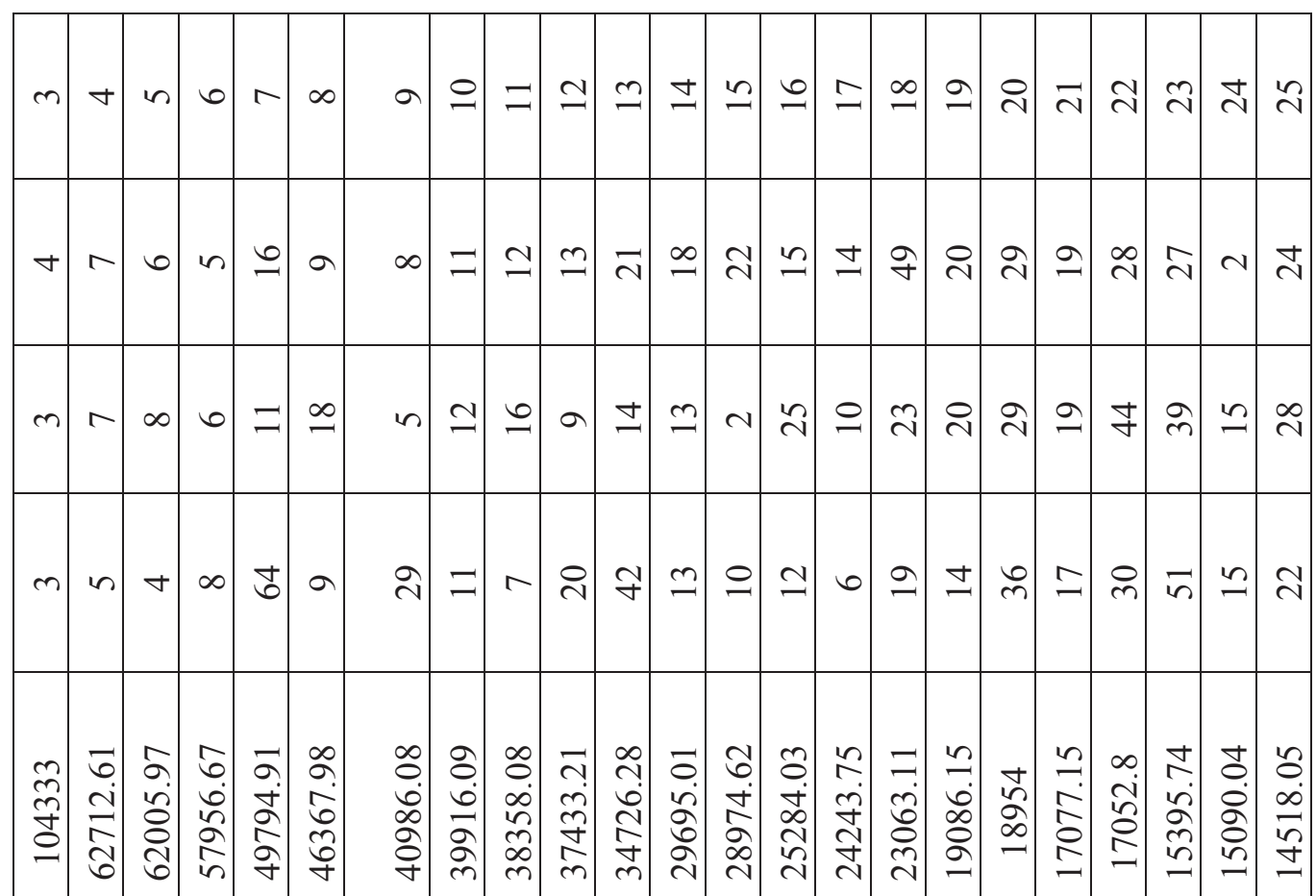

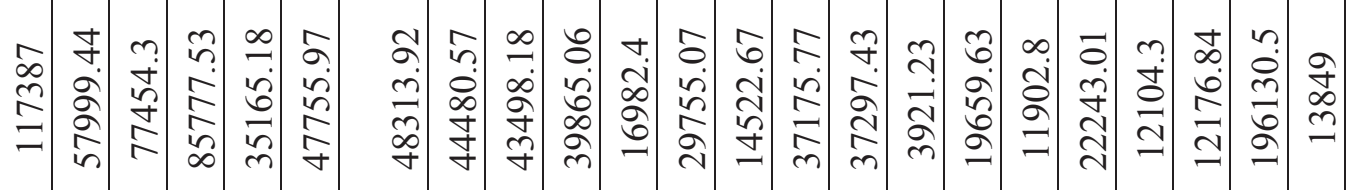

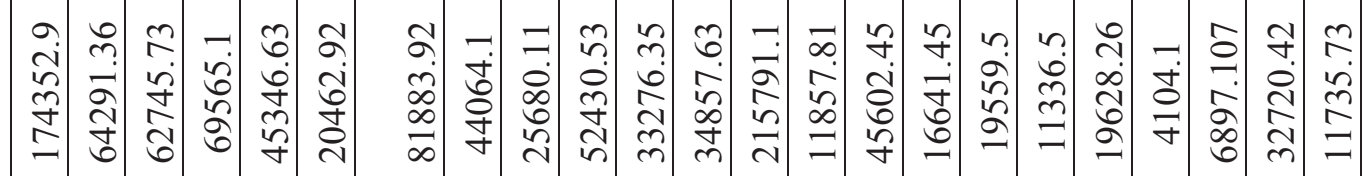

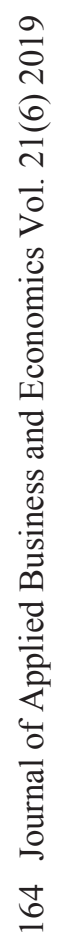

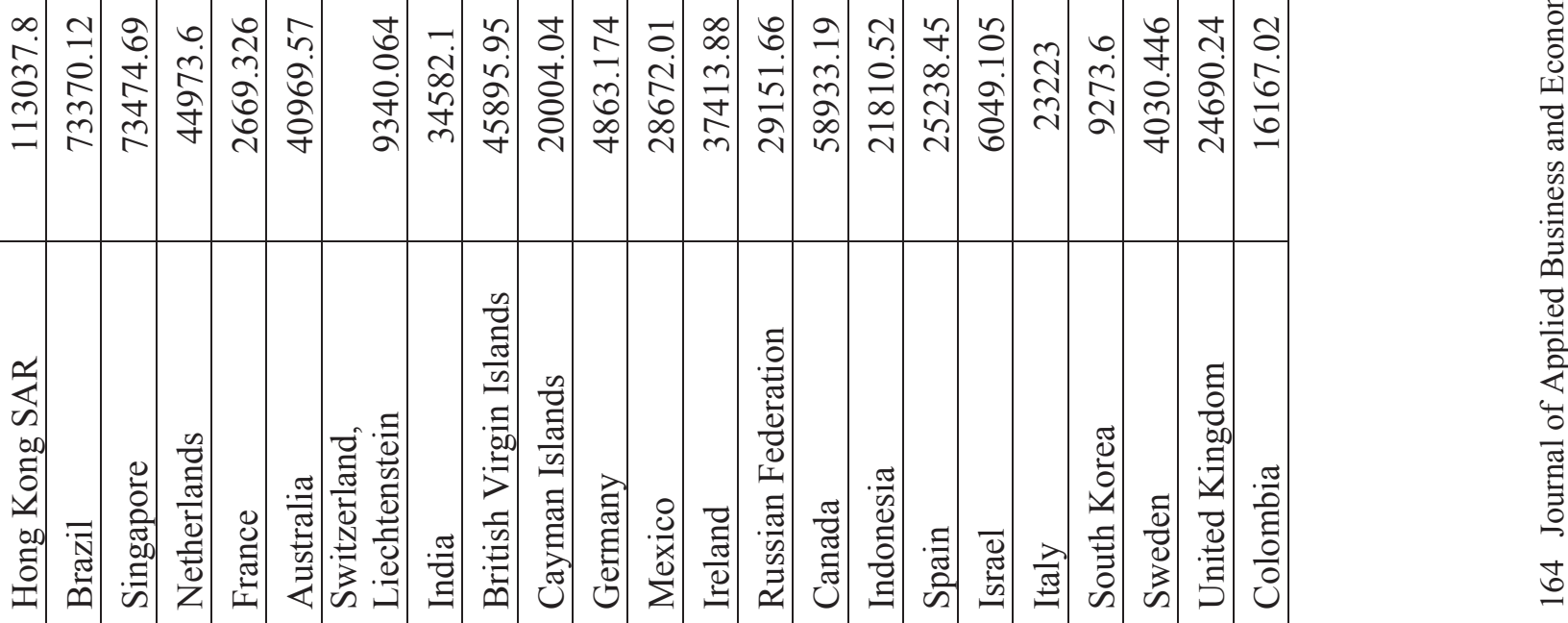

